\title{
Corporate Social Responsibility Disclosure of Sharia Banks in Indonesia
}

\section{Alwan Sri Kustono and Ardhya Yudistira Adi Nanggala}

University of Jember, Jl. Kalimantan No.37, Krajan Timur, Sumbersari, Kabupaten Jember, Jawa Timur 68121, Indonesia

\section{Abstract}

The purposes of this article is to investigate factors that influence Corporate Social Responsibility (CSR) reporting information at Indonesian sharia banks. The dependent variable of this study is the disclosure of corporate social responsibility. Independent variables are size of sharia banks, board of commissioner's size, company age, profitability of sharia banks. Sample used was 13 sharia banks that published annual reports and CSR reports in 2015 to 2017. Panel data were examined by regression. The result showed only firm size influence on CSR. The other independent variables do not influence the CSR reporting. Firm size is the predictor of how much content of CSR will be disclosed by management.

Corresponding Author:

Alwan Sri Kustono

Alwan.sri@gmail.com

Received: 29 January 2019

Accepted: 27 February 2019

Published: 24 March 2019

Publishing services provided by Knowledge E

(c) Alwan Sri Kustono and Ardhya Yudistira Adi Nanggala. This article is distributed under the terms of the Creative Commons Attribution License, which permits unrestricted use and redistribution provided that the original author and source are credited.

Selection and Peer-review under the responsibility of the $3 \mathrm{rd}$ ICEEBA Conference Committee.

\section{Background}

The Financial Services Authority (OJK) will require Financial Services Institutions (FSI), including issuers and public companies to implement sustainable financial principles in their business activities. gradually starting January 1, 2019. This obligation will be contained in OJK regulations (POJK) about the application of Sustainable Finance. Points setting the financial services authority Regulation Number 51/POJK. 03/2017 about application of Sustainable Finance for financial institutions, issuers, and public companies states that FSI that is required to implement Social Responsibility Environment (SRE) must allocate a portion of its SRE funds to support the implementation of Sustainable Finance.

Sustainable finance is defined as a form of overall support from the financial services sector to create sustainable economic growth derived from harmony between economic, social and environmental interests. The principle covers the principles of responsible investment, the principles of sustainable business practices and strategies, the principles of social and environmental risk management, including the principles of 
good governance. In addition, it also includes the principles of informative communication, inclusive principles, sustainable development priority economic sector principles, including the principles of coordination and collaboration. Information about corporate social responsibility is one of the information that must be submitted in the Sustainability Report.

In Indonesia, disclosures regarding social and environmental accounting are not specifically regulated in accounting standards, meaning that reporting of environmental information in the company's annual report is still difficult. Indonesian Accounting Association (IAI) states that entities can also provide additional reports such as value added statements, especially for industries where environmental factors play an important role and for industries that consider employees as groups of report users who play an important role.

The statement made the basis that IAl's concern was influenced by social and environmental problems arising from the company's business activities in Indonesia. The reporting trend of corporate social responsibility has developed in recent years. In 2011, of the 438 companies currently listed on the Indonesia Stock Exchange (IDX), there were only about 25 companies that made sustainability reports. As of 2015 , the total number of Indonesian publicly listed companies that reported sustainable reporting was 41 issuers. In 2016 it increased to 49 companies.

Corporate social responsibility practices are not only dominated by companies that touch business activities with the environment such as mining, manufacturing and chemical companies. Corporate social responsibility practices in Indonesia also done by banking industries. Various reports of corporate social responsibility can be found in the banking annual report. Banking industries in Indonesia implements the practice of corporate social responsibility is the influence of accounting developments that reflect themselves on the concern of social and environmental issue.

TABLE 1: Growth of Islamic Banks.

\begin{tabular}{l|c|c|c|} 
Type & $\begin{array}{c}\text { Number of } \\
\text { Banks }\end{array}$ & $\begin{array}{c}\text { Number of } \\
\text { Offices }\end{array}$ & $\begin{array}{c}\text { Total Assets } \\
\text { (Billions of } \\
\text { Rupiah) }\end{array}$ \\
\hline BUS & 13 & 1,822 & 292,289 \\
\hline UUS & 21 & 348 & 131,655 \\
\hline SRB & 168 & 458 & - \\
\hline Total & 202 & 2628 & 423,944 \\
\hline
\end{tabular}

Based on the principle of its business activities, banking in Indonesia is divided into conventional banks and Islamic banks (Law No. 21 of 2008). In its development, BUS (Islamic Bank) experienced very rapid growth. 
There were 3 BUS sharia banks in 2007 and the number increased in 2018; 13 BUS. With the increase in services throughout Indonesia, 13 sharia banks show that there is a tendency for the public to believe in transactions based on sharia principles. With the increase in stakeholder trust, it is appropriate for sharia banks as an entity to disclose corporate social responsibility. Disclosure of corporate social responsibility is a way for banks to communicate to stakeholders that the company give respond social and environmental impacts that arise.

TABLE 2: Growth of Sharia Banks Performance.

\begin{tabular}{|l|c|c|c|c|c|}
\hline & $\mathbf{2 0 1 2}$ & $\mathbf{2 0 1 3}$ & $\mathbf{2 0 1 4}$ & $\mathbf{2 0 1 5}$ & $\mathbf{2 0 1 6}$ \\
\hline CAR & 14.13 & 14.42 & 15.74 & 15.02 & 15.95 \\
\hline NPF & 2.22 & 2.62 & 4.95 & 4.84 & 4.42 \\
\hline NPM & 0.12 & 0.11 & 0.03 & 0.03 & 0.04 \\
\hline BOPO & 74.97 & 78.21 & 96.97 & 97.01 & 96.23 \\
\hline FDR & 100 & 100.32 & 86.66 & 88.03 & 85.99 \\
\hline ROA & 2.14 & 2.00 & 0.41 & 0.49 & 0.63 \\
\hline
\end{tabular}

The position of sharia banks must be a pilot financial institution in driving corporate social responsibility programs (Yusuf, 2010). Program corporate social responsibility Sharia banks must really touch the basic needs of the community to create equitable economic prosperity for the community.

According to Meutia (2010: 11), the form of corporate social responsibility is the disclosure or making of a report on corporate social responsibility. Theories regarding corporate social responsibility disclosure is an ideal thing in a Sharia bank is Sharia Enterprise theory. In sharia enterprise theory explains that God is the main source of trust while resources are owned by stakeholders is a mandate from God in which a responsibility is attached responsible for using the means and objectives set by the Supreme Giver of Trust (Meutia, 2010: 49).

Disclosure of corporate social responsibility in Indonesia refers to measurements based on the Global Reporting Initiative (Haniffa, 2002). Related to the need for disclosure of social performance in Islamic banking, currently is widely discussed about Islamic Social Reporting (Sofyani et al., 2012). The Islamic social reporting index is a benchmark measuring the implementation of the Sharia bank's social performance which contains a compilation of standard corporate social responsibility items set by Accounting and Auditing Organization for Islamic Financial Institutions ( AAOIFI). Social Islamic Index reporting is expected to be a benchmark for companies to do social responsibility especially entities based on sharia principles in Indonesia. 
Sharia bank CSR research in Indonesia shows the development of disclosure. Trisnawati (2015) used a sample of sharia bank financial reports and CSR publications for the period 2009 to 2011 concluded that the CSR disclosure score was relatively low, that is only around $30-40 \%$. The development of CSR reporting on Islamic banks in Indonesia is shown by Norti's research (2015). The result studies show that the disclosure of ISR index of 5 Islamic banks in Indonesia for four years until the yeaR2014 i.e. BMI 68.83\%, 71.47\% BSM, BNI Syariah 69.48\%, 60.35\% BSMI, BRI Syariah 57.73\%. Banks in the sample trying to report their activities in the bank's annual report. Sawitri et al. (2017) shows the better position of CSR reporting. In 2015 the level of CSR disclosure was in the range of $54 \%-86 \%$. In 2016 it remained in the same range, although some BUS showed an increase in CSR disclosures.

Various studies related to corporate social responsibility disclosure has been carried out by various researchers and shows the results diverse or inconsistent. Based on the results of previous inconsistent research, this study uses several factors that influence corporate social responsibility disclosure.

Firm size is one that is tested in research on the determinants of CSR. The research that indicate relationship between firm size on the disclosure of corporate social responsibility conducted by Sembiring (2005), Indrawati (2009), Untari (2010), Irmadariyani (2010), and Khasanah (2017). In contrast, Marpaung (2009) shows that firm size does not influence the disclosure of corporate social responsibility.

Relation of the size of the board of commissioners to the disclosure of corporate social responsibility also showed mixed results. Research shows there is a relationship between the size of the board of directors and the disclosure of corporate social responsibility conducted by Sembiring (2005) and Khasanah (2017). Research by Badjuri (2011), Febrina and Suaryana (2011) concluded that the size of the board of commissioners does not influence the disclosure of corporate social responsibility.

The relationship between the age of the company and the disclosure of corporate social responsibility also shows different results. Research shows the relationship between the age of the company and the disclosure of corporate social responsibility conducted by Untari (2010) while research conducted by Marpaung (2009), Irmadariyani (2010) found that the age of the company had no influence on the disclosure of corporate social responsibility.

The relationship of the company's profitability to the disclosure of corporate social responsibility also shows inconsistent results. That research shows that there is a relationship between the company's profitability toward corporate social responsibility disclosures conducted by Untari (2010), Badjuri (2011), Suryono ( 2011), Widiawati (2012), 
Widyayuni and Harto (2014) Higher profit companies have a tendency to policy intervention. The research conducted by Sembiring (2005), Apriwenni (2009), Febrina and Suaryana (2011), Sefrilia and Saftiana (2012), Khasanah (2017) and Kasih (2017) concluded that profitability does not influence corporate social responsibility disclosure.

Based on the background, the research problem is : are size, board size, age of Islamic banks and Islamic banks profitability influence disclosure of corporate social responsibility in sharia banks?

\section{Literature Review}

\subsection{Corporate social responsibility}

There are several definitions of corporate social responsibility expressed by various researchers and organizations. According to the World Bank in Sefrilia and Saftiana (2012) defines CSR as: commitment of business to contribute to sustainable economic development working with employees and their representatives, the local community and society at large to improve the quality of live, in ways that are both good for business and good for development. CSR is a business commitment to play a role in economic development that can work with employees and their representatives, the surrounding community and the wider community to improve the quality of life, in a manner that is good for business and development (Sefrilia and Saftiana, 2012).

Aspects contained in the definition are business people responsible for respecting and maintaining the environment. They also help improve the quality of life through community empowerment and investing in the community. Important issues to consider include: business ethics, community investment, environment, governance and accountability, human rights, marketplace, vision, mission and values, workplace. CSR activities includes four contexts, namely: the workplace, human right, supplier, products and service.

\subsection{Hypothesis development}

\subsubsection{Corporate social responsibility measures and disclosures}

The firm size is a scale that can determine the size of a company so that the company can be known whether a large company or vice versa (Irmadariyani, 2010). Some indicators 
determine firm size, namely by total assets, stock market value, number of employees and others.

Relationship between firm size and corporate social responsibility disclosure due to the larger the company, the company will increasingly active to show the public that the operations carried out by the company are in the regulated conditions. This is in line with the legitimacy theory that companies that have large size will get social pressure, economic politics is greater than outside the company so that the company will be more extensive in disclosing corporate social responsibility that is used to gain legitimacy from stakeholders.

In line with the research conducted by Sembiring (2005), Indrawati (2009), Apriwenni (2009), Irmadariyani (2010), Febriana and Suaryana (2011), Suryono and Prastiwi (2011), and Aryani and Zuchroh (2018) show a relationship between firm size and the disclosure of corporate social responsibility. Farooq et al. (2015) Large firms which have more resources will be more capable and flexible to use their funds for doing CSR. Then the hypothesis formulated in this study is:

$\mathbf{H}_{1}$ : Firm size influence disclosure of corporate social responsibility of sharia banks.

\subsubsection{Size of the board of commissioners and corporate social responsibility disclosures}

The board of commissioners is a representative of stakeholders in a company incorporated as a limited liability company that oversees the management of the company carried out by management and is responsible for determining whether management fulfills their responsibilities in developing and carrying out internal control of the company (Mulyadi, 2002). The board of commissioners also has the authority to provide direction or guidance and oversee company management.

The relationship of the board of commissioners with the disclosure of corporate social responsibility is the more number of commissioners in one the company will also be increasingly encouraged to be given to management to disclose corporate social responsibility. For example, the board of commissioners can monitor the performance of the company's management to be more influence. The commissioner will supervise the directors when they run its business. Sembiring (2005) states that the more members of the board of commissioners, the easier it will be to control management in carrying out activities, especially in conducting social responsibility disclosures. Dewi and Rahmawati (2010) found that there is a positive association between size commissioner board and CSR. 
In line with the research conducted by Sembiring (2005), Febriana and Suaryana (2011) showed a relationship between the size of the board of commissioners and the disclosure of corporate social responsibility. Then the hypothesis formulated in this study is:

$\mathbf{H}_{2}$ : Board of commissioners size influence disclosure of corporate social responsibility of sharia banks.

\subsubsection{Company age and corporate social responsibility disclosures}

Disclosure of corporate social responsibility is one of the items in the company's annual report that is needed by users of financial statements, especially investors in considering their investment decisions (Irmadariyani, 2010). Untari (2010) stated that a long-standing company showed that the company was able to compete with companies in the same field. Companies that have long been public companies will have more experience in disclosing their annual reports, they will know more about what is needed by users of financial statements (Irmadariyani, 2010). Untari (2010) states that the age of a company can show the existence of a company in its environment and increase investor confidence. This means that companies that stand first understand more about the benefits of corporate social responsibility disclosure.

The research conducted by Untari (2010) shows that there is a relationship between age and corporate social responsibility disclosure. Then the hypothesis formulated in this study is:

$\mathbf{H}_{3}$ : Company age influence disclosure of corporate social responsibility of sharia banks.

\subsubsection{Profitability and corporate social responsibility disclosures}

Profitability is a performance indicator carried out by management in managing corporate wealth (Suhardjanto, 2009). The profitability ratio used to assess the company's financial performance can help users of financial statements to assess the company's credibility.

Haniffa \& Cooke (2005) states that there is a relationship between profitability and corporate social responsibility disclosures as seen from the increasing number of profits obtained by the company so that the company can bear higher costs to make corporate 
social responsibility disclosure reports wider. It can be said that profitability has a positive influence on the disclosure of corporate social responsibility.

Research conducted by Badjuri (2009), Suryono and Prastiwi (2011) shows the relationship between profitability and corporate social responsibility disclosure. Ebiringa et al. (2013) found that profitability positively influences CSR. When companies have a high profit, it means the companies have the economic ability to encourage to do CSR. The hypothesis formulated in this study is:

$\mathbf{H}_{4}$ : Profitability influence disclosure of corporate social responsibility of sharia banks.

\section{Research Methods}

The type of research used is explanatory research, namely research that explains the relationship of a variable with other variables and examines the relationship between several variables through testing hypotheses. An explanatory research test is useful to strengthen or even reject the theory or hypothesis of existing research results. An explanatory research study also aims to explain the relationship between two or more symptoms or variables. The dependent variable of this study is the disclosure of corporate social responsibility and independent variables, namely the size of Sharia banks, the size of the Sharia bank's board of commissioners, the company age, profitability of sharia banks.

\subsection{Data source}

Data used in this research is secondary data and time series. According to Indriantoro and Supomo (2009: 147) secondary data is the source of research data obtained by researchers indirectly through the media. Time series data is data that consists of multiple objects but includes some particular time. In this study the data used is the annual report of all sharia banks in Indonesia obtained from the website.

\subsection{Population and sample}

The population used in this study is all sharia banks registered at Bank Indonesia. The sample is sharia banks registered until the yeaR2015- 2017. The sample selection method used in this study was purposive sampling. The sample selection in this study is based on the criteria : sharia banks registered with Bank Indonesia and publish annual report in 2015 to 2017 and not necessarily in a row. 


\subsection{Variable operational definition}

The definition of an independent variable according to Indriantoro and Supomo (2009: 63 ), is the type of variable that explains or influences other variables. In this study the independent variables that influence the dependent variable are as follows:

1. Firm size (X1). Variable size in a Sharia banks is measured using total assets. The indicator of total assets is used in determining firm size because companies that have large assets will have the possibility to make broader disclosures due to assets to finance boarding costs from these disclosures (Irmadariyani, 2010).

2. Size of the board of commissioners (X2). Variables in the size of the board of commissioners of sharia banks are measured using the number of board of commissioners consisting of president commissioners, independent commissioners, and commissioners (Hikmah, 2011).

3. Company Age (X3). Variable age in sharia banks are measured using length of the banks listed in Bank Indonesia.

4. Profitability (X4). This variable is measured by return on equity (ROE). Selection of return ratio on equity is based on the interests of shareholders in assessing the disclosure of corporate social responsibility carried out by the company on the invested capital.

5. Disclosure of corporate social responsibility measured using the Islamic Social index Reporting. Items in Islamic social reporting consist of six themes of disclosure, such as, investment and finance, governance of the organization, products and services, labor, social, and environmental (Othman and Thani, 2010).

\subsection{Results and Discussion}

Multiple regression analysis in this study was used to examine the influence of the size, size of the board of commissioners, age, profitability on the disclosure of corporate social responsibility of Islamic banks in Indonesia for the period 2015 to 2017. The results of multiple linear regression test are as follows in Table 3. The determination coefficient is used to measure the influence of the independent variable on the dependent variable. Adjusted R2 is used when evaluating the best regression model because its value can go up or down when the independent variable is added in a model. The greater the adjusted value $\mathrm{R}^{2}$ then the stronger the ability of the regression model obtained for explain the actual conditions. 
TABLE 3: Multiple Linear Regression Test Results.

\begin{tabular}{l|c|c|c|c|c|}
\hline & \multicolumn{2}{c|}{ No coefficient Standardized } & $\begin{array}{c}\text { Coefficient } \\
\text { Standardized }\end{array}$ & t-count & Sig.t \\
\hline Constants & B & Std. Error & Beta & \\
\hline Firm size & -0.502 & 0.392 & & -1.282 & 0.211 \\
\hline board of Commissioners & 0.033 & 0.014 & 0.516 & 2.323 & 0.028 \\
\hline Company age & -0.015 & 0.023 & -0.179 & -0.651 & 0.521 \\
\hline Profitability & 0.004 & 0.004 & 0.307 & 1.017 & 0.319 \\
\hline Company & 0.038 & 0.080 & 0.085 & 0.469 & 0.643 \\
\hline Note: R2 = 0.481; Adj R2 = 0.401; F=6,021; and Sig $=0.001$. & & & & \\
\hline
\end{tabular}

Based on the data in Table 3, it is known that the adjusted R2 value is 0.401 . This means that $40.1 \%$ variation in the dependent variable is the disclosure of corporate social responsibility can be explained by independent variables includes size, board size, age, profitability. The remaining 59.9\% (100\% - 40.1\%) is explained by other variables outside the research model.

\subsection{Hypothesis testing}

The $t$-test used to determine each independent variable in a model has a partial influence on the dependent variable with a significance level of $5 \%$. Based on the partial hypothesis test ( $t$-test), the test hypothesis with a significance level of $<0.05$ then $\mathrm{HO}$ is rejected and $\mathrm{Ha}$ accepted that significant independent variables influence the dependent variable. Meanwhile, if testing the hypothesis with a significance level $>0.05$ then received and accepted $\mathrm{HO}, \mathrm{Ha}$ rejected so that the independent variable does not significantly influence the dependent variable. Based on test data $t$ in Table 3 , the following results are obtained:

The size is proxied by the natural logarithm of the company's total assets. Regression coefficient value of variable size $\left(X_{1}\right)$ is 0.516 with a sig $t$-value of 0.028 . This suggests that $\mathrm{H} 1$ accepted so that firm size's influence on the disclosure of corporate social responsibility.

The size of the board of commissioners is proxied by the number of commissioners. The regression coefficient variable is the size of the board of commissioners $\left(X_{2}\right)$ of 0.179 with a sig $t$-value of 0.521 . This suggests that $\mathrm{H} 2$ rejected. Company's board size has no influence on the disclosure of corporate social responsibility.

Age is proxied by the length of time the company is registered with Bank Indonesia as a company that runs activities based on sharia principles. Regression coefficient value 
variable age $\left(X_{3}\right)$ is 0.307 with a sig $t$-value of 0.319 . This suggests that $\mathrm{H} 3$ rejected. Age does not influence the company's disclosure of corporate social responsibility.

Profitability is proxied by the ratio of the company's return on equity. The regression coefficient value variable profitability $\left(\mathrm{X}_{4}\right)$ is 0.085 with a sig $t$-value of 0.643 . This suggests that $\mathrm{H} 4$ rejected. Company's profitability does not influence the disclosure of corporate social.

\subsection{Size and disclosure corporate social responsibility}

The variable size is proxied by using the natural logarithm (In) of the total assets owned by the company. Based on the test results it is known that the size has a positive influence on the disclosure of corporate social responsibility. This means that the larger the size of a company the company will be more extensive in disclosing corporate social responsibility. The results of this study succeeded in supporting the theory of legitimacy regarding influence of size on the disclosure of corporate social responsibility. Companies that are larger or have large assets will have operating activities and greater influence on the community and the environment and have shareholders who pay attention to the social programs that are made by the company (Sembiring, 2005).

The larger the size of a Sharia bank, the larger the company will get social, political and economic pressure outside the company so that the company will increasingly make corporate social responsibility disclosures which is used to gain legitimacy from stakeholders. In relation to that Sharia banks in Indonesia have a large size (assets) so that the company will disclose corporate social responsibility more broadly to get legitimacy (blessings) from Allah SWT and the legitimacy of the relevant stakeholders to achieve the sharia objectives set by the Islamic commercial banks.

The results of this study are consistent with Sembiring (2005), Irmadariyani (2010), Ariyani and Zuchroh (2018) which states that size has a positive influence on corporate social responsibility disclosure. This study differs from Marpaung (2009) which states that the measure does not influence the disclosure of corporate social responsibility. This difference is due to the different size of each object of research conducted. Companies as objects of research that have a large average size will disclose corporate social responsibility more broadly than companies that have small size. First hypothesis $(\mathrm{H} 1)$ is accepted so that the size variable influences the disclosure of corporate social responsibility. 


\subsection{Board of commissioners size and corporate social responsibility disclosures}

Board of commissioner's size is proxied by using the number of board of commissioners including the independent board of commissioners owned by the company. Based on the test results it is known that the size of the board of commissioners does not influence the disclosure of corporate social responsibility. This means that the larger the size of the board of commissioners of a company will not influence the company in disclosing corporate social responsibility. This is because the number of commissioners owned by the sharia banks is not influence in monitoring and giving direction to the management of sharia banks to disclose corporate social responsibility based on Islamic social reporting.

Board of commissioners only provides direction and recommendations regarding financial performance issues particularly capital, profitability, risk profiles, and providing input on various financial aspects of the bank's future business plans. In addition, according to Uwuigbe in Effendi (2012) that with so many councils the commissioner will make more and more interests to be carried out by the board of directors in giving direction to the board of directors so that disclosure of CSR will not be maximized because of a conflict of interest.

The results of this study are consistent with the research of Irmadariyani (201 0), Febrina and Suaryana (2011). Badjuri (2011) and Ariyani and Zuchroh (2018) which state that the size of the board of commissioners does not influence the disclosure of corporate social responsibility. While the results of this study differ from Sembiring (2005) which states that the size of the board of directors influences the disclosure of corporate social responsibility. Differences in research results are caused by the perspective and different actions from the board of commissioners in each company in various studies related to directives given to management regarding disclosure of corporate social responsibility. The second hypothesis $(\mathrm{H} 2)$ is rejected. The size of the board of commissioners does not influence the disclosure of corporate social responsibility.

\subsection{Company age and corporate social responsibility disclosures}

The age of the company is proxied by the length of the company registered with Bank Indonesia as a company that runs activities based on sharia principles. Based on the test results it is known that age does not influence the disclosure of corporate social responsibility. This means that the longer a company stands as a sharia entity will not influence the company in disclosing corporate social responsibility. 
The results of this study are consistent with the research of Irmadariyani (2010) which states that age does not influence the disclosure of corporate social responsibility. While the results of this study are different from Untari (2010) states that age influences the disclosure of corporate social responsibility. The experience of sharia banks while operating for a long time as a sharia unit makes the company better understand the positive impact of corporate social responsibility disclosure for the company. Therefore, the third hypothesis $(\mathrm{H} 3)$ is rejected so that the age variable does not influence the disclosure of corporate social responsibility.

\subsection{Profitability and corporate social responsibility disclosures}

The company's profitability is proxied by the ratio of return on equity. Based on the test results it is known that profitability does not influence the disclosure of corporate social responsibility. This means that the greater the profitability of the company will not influence the company in disclosing corporate social responsibility. In relation to the sharia banks do not disclose corporate social responsibility on the basis of profitability obtained, but on profitability obtained last year (Sembiring, 2005).

Cost of corporate social responsibility disclosure make the company does not undertake disclosure more widely at the time of last year's profitability declined. If increased profitability in the past year, the implementation of the disclosure of corporate social responsibility this year will be more widely used because their earnings to the disclosure of corporate social responsibility.

The results of this study are consistent with the research of Sembiring (2005), Apriwenni (2009), Febriana and Suaryana (2011), Sefrilia and Saftiana (2012) which state that profitability does not influence the disclosure of corporate social responsibility. While the results of this study are different from Badjuri (2011) which states that profitability influences the disclosure of corporate social responsibility. The difference between the results of research is because the principle of each company perceives the importance of disclosing corporate social responsibility in terms of the profitability obtained. Sharia banks view corporate social responsibility disclosures as a mandatory matter to achieve the objectives of sharia so that the disclosure based on Islamic social reporting does not depend on the profitability obtained by Islamic banks. Therefore, the fourth hypothesis $(\mathrm{H} 4)$ is rejected. Profitability has no influence on the disclosure of corporate social responsibility. 


\section{Conclusions}

\subsection{Conclusion}

Based on the results of research and hypothesis testing that has been done, the conclusions of this study as follows:

1. Firm size influences the disclosure of corporate social responsibility based on Islamic social reporting in sharia banks in Indonesia. This means that the greater the assets of Sharia banks, the more extensive corporate social responsibility disclosures are carried out.

2. The size of the board of commissioners does not influence the disclosure of corporate social responsibility based on Islamic social reporting in Islamic banks in Indonesia. This means that the more boards of commissioners they hold will not influence broadly the disclosure of corporate social responsibility by sharia banks.

3. The age of the company does not influence the disclosure of corporate social responsibility based on Islamic social reporting in sharia banks in Indonesia. This means that the longer a Sharia bank is established; it will not influence the broad disclosure of corporate social responsibility carried out.

4. Profitability does not influence the disclosure of corporate social responsibility based on Islamic social reporting in sharia banks in Indonesia. The profitability obtained does not influence broadly the disclosure of corporate social responsibility by sharia banks.

\subsection{Limitations}

There are several limitations in this study:

1. The use of the Islamic social reporting index with dummy causes the quality of corporate social responsibility disclosure to be neglected because it only looks at the quantity of disclosure that is the presence or absence of the information presented. The measurement of corporate social responsibility disclosure is more concerned with quality and not only fixes on the presence or absence of Islamic social reporting items in Islamic commercial banks such as evaluating corporate social responsibility reports about the benefits of implementing corporate social responsibility perceived by the community and environment. 
2. The use of a board of commissioners as proxy with all the number of commissioners: president commissioner, the board of commissioners, the independent board of directors does not reflect the maximum results of CSR disclosure because of a conflict of interest in regulating and giving direction to the Sharia bank directors. Proxy of the board of commissioners can use the number of independent board of directors because it reflects the supervision and direction that is not affiliated with other interests in the management of CSR disclosure.

3. Sharia banks are expected to disclose corporate social responsibility based on Islamic social reporting wider in order to enhance the image of sharia entities in carrying out activities that are social and environmental responsible to stake holder and achieving the objectives of sharia.

\section{References}

[1] Aburizal, I. N. (2011). Pengaruh Pembiayaan dan Kas Terhadap Tanggung jawab sosial korporasi Melalui Laba Sebagai Variabel Intervening (Pada Bank Umum Syariah di Indonesia). Thesis, Universitas Jember.

[2] Apriwenni, P. (2009). Faktor-Faktor Yang Mempengaruhi Pengungkapan Tanggung jawab sosial korporasi Pada Laporan Tahunan Perusahaan Untuk Industri Manufaktur Tahun 2008. Jurnal Ekonomi dan Bisnis, vol. 6, no. 1.

[3] Aryani, D. N. and Zuchroh, I. (2018). GCG, ROE and Size on CSR based on Sharia Enterprises Theory. Tazkia Islamic Finance and Business Review Volume, vol. 12, no. 1, pp. 61-80.

[4] Badjuri, A. (2011). Faktor-Faktor Fundamental, Mekanisme Coorporate Governance, Pengungkapan Coorporate Social Responsibility (CSR) Perusahaan Manufaktur dan Sumber Daya Alam Di Indonesia. Jurnal Dinamika Keuangan dan Perbankan, vol. 3, no. 1.

[5] Bank Indonesia. (2011). Statistik Perkembangan Perbankan Syariah. Direktorat Perbankan Syariah.

[6] Chairi, A. (2001). Teori Akuntansi. Semarang: Badan Penerbit Universitas Diponegoro.

[7] Ebiringa, O. T., et al. (2013). Effect of firm size and profitability on corporate social disclosures: The Nigerian oil and gas sector in Focus. British Journal of Economics, Management and Trade, vol. 3, no. 4, pp. 563-574.

[8] Effendi, B. (2012). Pengaruh Dewan Komisaris Terhadap Environmental Disclosure Pada Perusahaan Manufaktur Yang Listing Di Bei Tahun 2008-2011. Jurnal Riset Akuntansi Indonesia. 
[9] Farooq, S. U., Ullah, S., and Kimani, D. (2015). The relationship between corporate governance and Corporate Social Responsibility (CSR) disclosure: Evidence from the USA. Abasyn Journal of Social Sciences, vol. 8, no. 2, pp. 197-212.

[10] Febriana and Suryana, A. (2011). Faktor-Faktor yang Mempengaruhi Kebijakan Pengungkapan Tanggung Jawab Sosial dan Lingkungan Pada Perusahaan Manufaktur Di Bursa Efek Indonesia. SNA XIV. Aceh.

[11] Fitria, S. and Hartanti, D. (2010). Studi Perbandingan Pengungkapan Berdasarkan Global Reporting Initiative Indeks dan Islamic Social Reporting Indeks. SNA XIII. Purwokerto.

[12] Ghozali, I. (2011). Aplikasi Analisis Multivarian Dengan Program SPSS. Semarang: Badan Penerbit Universitas Diponegoro.

[13] Haniffa, R. (2002). Social reporting disclosure an Islamic perspective. Indonesian Management \& Accounting Research, pp. 128-146.

[14] Haniffa, R. and Cooke, T. (2005). The Impact of culture and governance on corporate social reporting. Journal of Accounting and Public Policy, pp. 391-430.

[15] Hernita, W. (2011). Pengungkapan Corporate Social Responsibility Terhadap Profitabilitas Perusahaan. Thesis, Universitas Jember.

[16] Hikmah, N. and Chairina. (2011). Faktor-Faktor yang Mempengaruhi Luas Pengungkapan Corporate Governance Dalam Laporan Tahunan Perusahaan Perbankan yang Terdaftar di BEI. Proceeding SNA XIV. Aceh.

[17] Ikatan Akuntan Indonesia. (2009). Standar Akuntansi Keuangan. Jakarta: Salemba Empat.

[18] Indrawati, N. (2009). Pengungkapan Tanggung Jawab Sosial Korporasi (CSR) Dalam Annual Report Serta Pengaruh Political Visibility Dan Economic Performance. Pekbis Jurnal, vol. 1, no. 1.

[19] Indriantoro, N. and Supomo, B. (2009). Metodologi Penelitian Bisnis Untuk Akuntansi dan Manajemen. Yogyakarta: BPFE.

[20] Irmadariyani, R. (2010). Pengaruh Faktor-Faktor Non Keuangan Terhadap Pengungkapan Tanggung Jawab Sosial Pada Laporan Tahunan Perusahaan Perbankan Publik. Jurnal IImiah Inovasi, vol. 10, no. 13, pp. 193-205.

[21] Kartini, D. (2009). Tanggung Jawab Sosial Korporasi Transformasi Konsep Sustainability Management Dan Implementasi Di Indonesia. Bandung: Refika-Aditama.

[22] Mansur, S. (2012). Pelaporan Tanggung Jawab Sosial Korporasi (CSR) Perbankan Syariah Berdasarkan Perspektif Syariah Enterprise Theory. Thesis, Universitas Hasanuddin. 
[23] Marpaung, A. Z. (2009). Analisis Faktor-Faktor yang Mempengaruhi Pengungkapan Sosial (Social Disclosure) dalam Laporan Keuangan Tahunan. Thesis, Universitas Sumatera Utara.

[24] Meutia, I. and Febrianti, D. (2017). Islamic social reporting in Islamic banking: Stakeholders theory perspective. Paper presented at the SHS Web of Conferences, p. 34 .

[25] Meutia, I. (2010). Menata Pengungkapan CSR di Bank Is/am (Suatu Pendekatan Kritis). Jakarta: Citra Pustaka, Indonesia.

[26] Mulyadi. (2002). Auditing, vol. 1 (sixth edition). Jakarta: Salemba Empat.

[27] Othman, R. and Thani, A. (2010). Islamic social reporting of listed companies in Malaysia. International Business \& Economics Research Journal, vol. 9, no. 4.

[28] Sefrilia, M. and Saftiana, Y. (2012). Pengaruh Kepemilikan Saham dan Profitabilitas Terhadap Pengungkapan Tanggung jawab sosial korporasi (CSR). Jurnal Ekonomi dan Informasi Akuntansi, vol. 2, no. 2.

[29] Sembiring, E. R. (2005). Karakteristik Perusahaan dan Pengungkapan Tanggung Jawab Sosial: Study Empiris Pada Perusahaan yang Tercatat Di Bursa Efek Jakarta. Proceeding SNA VIII. Solo.

[30] Sofyani, H., et al. (2012). Islamic Social Reporting Index Sebagai Model Pengukuran Kinerja Sosial Perbankan Sosial. Jurnal Dinamika Akuntansi, vol. 4, no. 1.

[31] Sugiyono. (2007). Metode Penelitian Bisnis. Bandung: Alfabeta.

[32] Suhardjanto, D. and Miranti, L. (2009). Indonesian Environmental Reporting Index dan Karakteristik Perusahaan. Journal of Accounting and Auditing Indonesia, vol. 13, no. 2.

[33] Sunyoto, D. (2011). Praktik SPSS Untuk Kasus. Yogyakarta: Muha Medika.

[34] Suryono, H. and Prastiwi, A. (2011). Pengaruh Karakteristik Perusahaan dan Corporate Governance Terhadap Praktik Pengungkapan Sustainability Report. SNA XIV. Aceh.

[35] Suwardjono. (2010). Teori Akuntansi Perekayasaan Pelaporan Keuangan. Yogyakarta: BPFE.

[36] Triyuwono, I. (2007). Mengangkat "Sing Liyan" Untuk Formulasi Nilai Tambah Syari'ah. Proceeding SNA X Unhas, pp. 1-21.

[37] Undang-Undang No. 21 Tahun 2008 Tentang Perbankan Syariah. Lembaran Negara Republik Indonesia Tahun 2008. Jakarta: Sekretariat Negara Republik Indonesia.

[38] Undang-Undang No. 40 Tahun 2007 Tentang Perseroan Terbatas. Lembaran Negara Republik Indonesia Tahun 2007. Jakarta: Sekretariat Negara Republik Indonesia. 
[39] Untari, L. (2010). Effect on company characteristics CSR disclosure in corporate annual report of consumption listed in Indonesia Stock Exchange. Thesis, Universitas Gunadarma.

[40] Nil, U. U., Egbide, B.-C., and Ayokunle A. M. (2011). The effect of board size and board composition on firms corporate environmental disclosure: A study of selected firms in Nigeria. Acta Universitatis Danubius, vol. 7, no. 5 pp. 164-176.

[41] Winarno, W. W. (2009). Analisis Ekonometrika dan Statistik Dengan Eviews. Yogyakarta: UPP STIM YKPN.

[42] Yusuf, Y. (2010). Aplikasi CSR Pada Bank Syariah: Suatu Pendekatan Maslahah Dan Maqasid Syariah. EKSIBISI, vol. 4, no. 2. 